
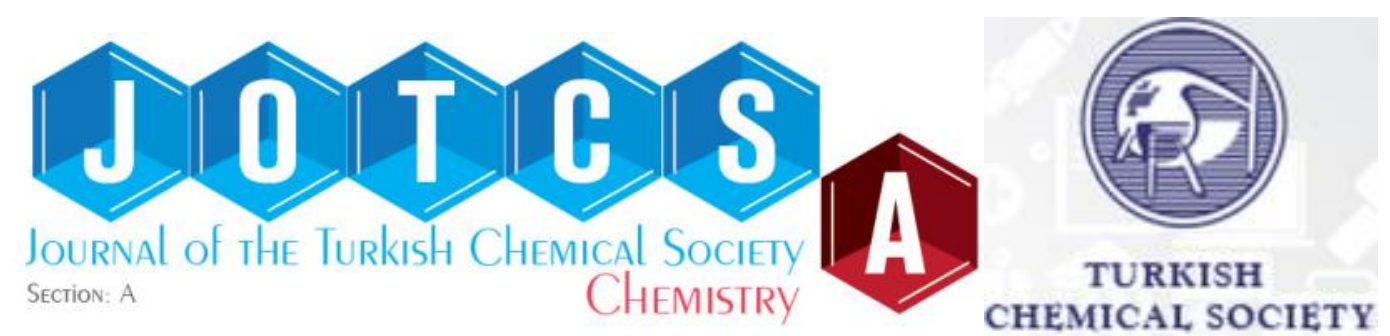

\title{
Synthesis and characterization of Ti-/Zr-diphenylpropanedione complexes and their application in the ring opening polymerization of $\varepsilon$-caprolactone
}

\author{
Yağmur Gökalp $\square$, Asgar Kayan* $\square$ iD
}

Department of Chemistry, Kocaeli University, Kocaeli, 41380, Turkey.

Abstract: The purpose has been to achieve a controlled ring-opening polymerization of $\varepsilon^{-}$ caprolactone, resulting in polymers with desirable properties such as high molecular weight, low polydispersity index, and highly regio-/stereo regular forms. Therefore, it is important to synthesize single site or reduced number of active site metal alkoxide compounds as catalysts. $\operatorname{Ti}(\mathrm{IV}) / \mathrm{Zr}$ (IV) diphenylpropanedione complexes were synthesized by reactions of titanium or zirconium alkoxides with diphenylpropanedione (dion) ligand. The obtained complexes were characterized by nuclear magnetic resonance $\left({ }^{1} \mathrm{H}-,{ }^{13} \mathrm{C}-\mathrm{NMR}\right)$, high resolution mass (HRMS), Fourier transform infrared (FTIR) spectroscopies and elemental analysis. These compounds were tested as catalysts for the ring opening polymerization of $\varepsilon$-caprolactone. The structure of poly-caprolactone (PCL) was analyzed by some spectroscopic techniques (NMR, FTIR) and gel permeation chromatography (GPC). In this work, all $\mathrm{Ti}$-/Zr-complexes were effective over polymerization of $\varepsilon$-caprolactone in solventless environment. Consequently, $\varepsilon$-caprolactone polymers were obtained different average molecular weights between 7000-34000 Da with the PDI values of 1.14-1.60.

Keywords: Metal alkoxide, catalyst, ring opening, diphenylpropanedione.

Submitted: May 30, 2018. Accepted: August 16, 2018.

Cite this: Gökalp Y, Kayan A. Synthesis and characterization of Ti-/Zr-diphenylpropanedione complexes and their application in the ring opening polymerization of $\varepsilon$-caprolactone. JOTCSA. 2018;5(3):1095-104.

DOI: http://dx.doi.org/10.18596/jotcsa.428666.

*Corresponding author. E-mail: akayan@kocaeli.edu.tr.

\section{INTRODUCTION}

The reactions between tetraalkoxy titanium or zirconium precursors and $\beta$-diketones and $\beta$ diketoesters have been known for over 30 years. Structures of titanium and zirconium $\beta$ diketonate complexes for the ethoxide, $n$ propoxide and other derivatives were prepared by different research groups (1-4). The allylacetoacetate and other derivatives were later prepared by Hoebbel, Schubert and co-workers (5-7). However, it is still unclear whether the complexes are monomeric, dimeric or oligomeric. For example, $\left[\mathrm{Ti}(\mathrm{acac})(\mathrm{OMe})_{3}\right]_{2}$ compound is binuclear, centrosymmetric structures with asymmetric alkoxide bridges (8). In the reactions of titanium or zirconium alkoxides with $\beta$ diketonates, $\beta$-diketoesters and carboxylates the third or fourth alkoxy groups are not replaced with these organic chelate ligands because of a preferred coordination number of six or higher for metals $(9,10)$.

It is important to stabilize the titanium or zirconium center with $\beta$-diketone ligand and also important to reduce the number of active alkoxy groups to prepare single-site or doublesite titanium or zirconium complexes for catalytic activity. There are many examples of the use of metal-alkoxides based catalytic systems in polymerization reactions for manufacturing polymeric substances such as polyether, polylactone, and poly-lactides (11- 
14). Due to their biocompatibility and biodegradability, these polymers have a lot of potential usage in medical, agricultural, and packaging areas (12-15).

Catalysts including single-site or reduced number of alkoxide groups stabilized with $\beta$ diketone have had a breakthrough impact in polymer synthesis. With the aim of these catalysts' molecular weights, molecular weight distributions and stereochemistry of polymers and copolymers can be controlled (15). The general formula of these catalysts are LnMOR or LnM(OR)2 (M:Metal, Ln: $\beta$-diketone) where the $O R$ is an alkoxy group that initiates the polymerization $(16,17)$.

In this study, our main objective is to prepare single site or double sites active catalysts by using different mole ratio of metal alkoxides and diphenylpropanedione and to characterize their structure by a combination of FTIR, ${ }^{1} \mathrm{H}-$ NMR, ${ }^{13} \mathrm{C}-\mathrm{NMR}$, HRMS spectroscopies and elemental analysis technique. The second objective is to see their catalytic efficiency on the ring opening polymerization of $\varepsilon$ caprolactone. Finally, it is also important to characterize poly- $\varepsilon$-caprolactone by gel permeation chromatography (GPC), ${ }^{1} \mathrm{H}-\mathrm{NMR}$ and ${ }^{13} \mathrm{C}-\mathrm{NMR}$, and FTIR spectroscopies.

\section{EXPERIMENTAL}

\section{Materials and Instrumentation}

Zirconium(IV) butoxide $\left(\mathrm{C}_{16} \mathrm{H}_{36} \mathrm{O}_{4} \mathrm{Zr}\right.$, \%80, Aldrich), zirconium(IV) propoxide $\left(\mathrm{C}_{12} \mathrm{H}_{28} \mathrm{O}_{4} \mathrm{Zr}\right.$, $\% 70$, Aldrich), titanium(IV) butoxide $\left(\mathrm{C}_{16} \mathrm{H}_{36} \mathrm{O}_{4} \mathrm{Ti}\right.$, \%97), titanium(IV) isopropoxide $\left(\mathrm{C}_{12} \mathrm{H}_{28} \mathrm{O}_{4} \mathrm{Ti}\right.$, \%97, Aldrich), 3-diphenyl-1,3propanedione $\left(\mathrm{C}_{15} \mathrm{H}_{12} \mathrm{O}_{2}, \% 98\right.$, Aldrich), and $\varepsilon$ -caprolactone $\left(\mathrm{C}_{6} \mathrm{H}_{10} \mathrm{O}_{2}\right.$, Alfa Aesar) were used as received. Solvents such as n-butanol $\left(\mathrm{C}_{4} \mathrm{H}_{9} \mathrm{OH}, 99 \%\right.$, Aldrich), isopropanol $\left(\mathrm{C}_{3} \mathrm{H}_{7} \mathrm{OH}\right.$, Aldrich), and others were dried over activated $4 \AA$ molecular sieves before use. Polymerization reactions were carried out under nitrogen atmosphere.

The infrared spectra of synthesized compounds and $\mathrm{PCL}$ were recorded on a Bruker Tensor 27 FTIR spectrometer using single reflection ATR universal plate of diamond crystal. The Ti-/Zr-compounds, and PCL were scanned from 400 to $4000 \mathrm{~cm}^{-1}$ with a resolution of $4 \mathrm{~cm}^{-1}$. ${ }^{1} \mathrm{H}$ and ${ }^{13} \mathrm{C}\left[{ }^{1} \mathrm{H}\right] \mathrm{NMR}$ measurements were carried out with a Bruker $400 \mathrm{MHz}$ spectrometers. The elemental analyses were carried out on a LECO CHNS932 elemental analyzer.

Mass spectrometry (SCIEX 4000 QTRAP LCMS/MS, HRMS) were used for measuring the molecular masses of complexes with electrospray ionization (ESI \pm ) method. GPC analysis was performed at $30^{\circ} \mathrm{C}$ on a Shimadzu prominence GPC system equipped with a RID-10A refractive index detector, a LC20AD solvent delivery unit, a CTO10AS column oven and a set of two columns, PSS SDV $5 \mu \mathrm{L} 1000 \AA$ and PSS SDV $5 \mu \mathrm{L} 50 \AA$. THF (HPLC grade) was used as the mobile phase at $1.0 \mathrm{~mL} / \mathrm{min}$. The sample concentration was $10 \mathrm{mg} / 5 \mathrm{~mL}$ and the injection volume was $50 \mu \mathrm{L}$. The calibration curve was made with polystyrene standards covering the molecular weight range from 162 to $34,300 \mathrm{Da}$.

\section{Reaction of titanium(IV) butoxide with 1,3-diphenyl-1,3-propanedione in 1:1 mole ratio (1) \\ The reaction of 1,3-diphenyl-1,3-} propanedione $\left(2.0 \times 10^{-3} \mathrm{~mol}, 0.46 \mathrm{~g}\right)$ with titanium n-butoxide $\left(2.0 \times 10^{-3} \mathrm{~mol}, 0.70 \mathrm{~g}\right)$ in $20 \mathrm{~mL}$ of $\mathrm{n}$-butanol was carried out similarly to the preceding reaction. ${ }^{1} \mathrm{H}-\mathrm{NMR}\left(\mathrm{CDCl}_{3}, \mathrm{ppm}\right)$ : $\delta 1.03\left(\mathrm{t}, \mathrm{CH}_{3}, \mathrm{OBu}\right), 1.53\left(\mathrm{~m}, \mathrm{CH}_{3}-\mathrm{C}_{2}, \mathrm{OBu}\right)$, 1.78 (pentet, $\left.\mathrm{CH}_{2}-\mathrm{CH}_{2} \mathrm{O}, \mathrm{OBu}\right), 3.73$ ( $\mathrm{t}, \mathrm{J}=6.40$ $\mathrm{Hz}, \mathrm{CH}_{2} \mathrm{O}, \mathrm{OBu}$, cis to dion), 4.74 ( $\mathrm{t}, \mathrm{J}=6.56$ $\mathrm{Hz}, \mathrm{CH}_{2} \mathrm{O}, \mathrm{OBu}$, trans dion), $7.07(1 \mathrm{H}, \mathrm{OC}-$ $\underline{\mathrm{H}}=$, dion), $7.38\left(2 \mathrm{H}, \mathrm{C}_{6} \mathrm{H}_{5}\right.$, dion), $7.46(1 \mathrm{H}$, $\mathrm{C}_{6} \mathrm{H}_{5}$, dion), $7.62\left(3 \mathrm{H}, \mathrm{C}_{6} \mathrm{H}_{5}\right.$, dion), $7.94(2 \mathrm{H}$, $\mathrm{C}_{6} \mathrm{H}_{5}$, dion), $8.30\left(2 \mathrm{H}, \mathrm{C}_{6} \mathrm{H}_{5}\right.$, dion). ${ }^{13} \mathrm{C}-\mathrm{NMR}$ $\left(\mathrm{CDCl}_{3}, \mathrm{ppm}\right): \delta 14.10\left(\mathrm{CH}_{3}, \mathrm{OBu}\right), 19.39$ $\left(\mathrm{CH}_{3}-\underline{\mathrm{CH}_{2}}, \mathrm{OBu}\right), 35.30\left(\underline{\mathrm{CH}}_{2}-\mathrm{CH}_{2} \mathrm{O}, \mathrm{OBu}\right)$, $73.17\left(\mathrm{CH}_{2} \mathrm{O}, \mathrm{OBu}\right.$, cis to dion), $76.82\left(\mathrm{CH}_{2} \mathrm{O}\right.$, $\mathrm{OBu}$, trans to dion), $94.93\left(\mathrm{OC}-\mathrm{CH}_{2}-\mathrm{CO}\right.$, dion, keto-form, the ratio of keto to enol form is $\sim 1 / 5$ ), 96.13 (dyad, OC- $\mathrm{CH}=$, dion), 127.81138.64 ( $\mathrm{C}=\mathrm{C}, \mathrm{C}_{6} \mathrm{H}_{5}$, dion), 182.29 ( $\mathrm{CH}=\mathrm{C}-\mathrm{O}$, dion, enol form), 184.84 ( $\mathrm{C}=\mathrm{O}$, dion). FTIR $\left(\mathrm{cm}^{-1}\right)$ : 3056, 2954, 2927, 2869, 2838, 1594, $1546,1518,1476,1363,1222,1071,745$, $682,617,430$. Mass spectrum: $529.184 \mathrm{Da}$ for molecular ion $\left[\mathrm{Ti}\left(\mathrm{OBu}^{\mathrm{n}}\right)_{3} \text { (dion) }+\mathrm{K}\right]^{+}$ $\left(=\mathrm{TiC}_{27} \mathrm{H}_{38} \mathrm{O}_{5}+\mathrm{K}^{+}\right)$or $\left[\mathrm{Ti}\left(\mathrm{OBu}^{\mathrm{n}}\right)_{3} \text { (dion) }+\mathrm{H}\right]^{+}$ $\left(=\mathrm{TiC}_{27} \mathrm{H}_{38} \mathrm{O}_{5}+\mathrm{H}^{+}\right)$.

\section{Reaction of titanium(IV) butoxide with 1,3-diphenyl-1,3-propanedione in 1:2 mole ratio (2) \\ The reaction of 1,3-diphenyl-1,3-} propanedione $\left(4.0 \times 10^{-3} \mathrm{~mol}, 1.0 \mathrm{~g}\right)$ with titanium n-butoxide $\left(2.0 \times 10^{-3} \mathrm{~mol}, 0.70 \mathrm{~g}\right)$ in $20 \mathrm{~mL}$ of $\mathrm{n}$-butanol was carried out similarly to the preceding reaction. ${ }^{1} \mathrm{H}-\mathrm{NMR}\left(\mathrm{CDCl}_{3}, \mathrm{ppm}\right)$ : $\delta 0.95\left(\mathrm{t}, \mathrm{CH}_{3}, \mathrm{~J}=7.4 \mathrm{~Hz}, \mathrm{OBu}\right), 1.54\left(\mathrm{CH}_{3}-\mathrm{CH}_{2}\right.$, $\mathrm{OBu}$ ), 1.79 (pentet, $\left.\mathrm{C}_{2}-\mathrm{CH}_{2} \mathrm{O}, \mathrm{OBu}\right), 4.74$ (t, $\left.\mathrm{CH}_{2} \mathrm{O}, \mathrm{J}=6.58 \mathrm{~Hz}, \mathrm{OBu}\right), 7.07(2 \mathrm{H}, \mathrm{OC}-\mathrm{C} \underline{\mathrm{H}}=$, dion), $7.40\left(4 \mathrm{H}, \mathrm{C}_{6} \mathrm{H}_{5}\right.$, dion), $7.49\left(2 \mathrm{H}, \mathrm{C}_{6} \mathrm{H}_{5}\right.$, dion), $7.64\left(6 \mathrm{H}, \mathrm{C}_{6} \mathrm{H}_{5}\right.$, dion), $7.95\left(4 \mathrm{H}, \mathrm{C}_{6} \mathrm{H}_{5}\right.$, dion), $8.30\left(4 \mathrm{H}, \mathrm{C}_{6} \mathrm{H}_{5}\right.$, dion). ${ }^{13} \mathrm{C}-\mathrm{NMR}\left(\mathrm{CDCl}_{3}\right.$, ppm): $\delta 14.14\left(\mathrm{CH}_{3}, \mathrm{OBu}\right), 19.37\left(\mathrm{CH}_{3}-\mathrm{CH}_{2}\right.$, $\mathrm{OBu}), 35.31\left(\mathrm{CH}_{2}-\mathrm{CH}_{2} \mathrm{O}, \mathrm{OBu}\right), 78,60,76.84$ $\left(\mathrm{CH}_{2} \mathrm{O}, \mathrm{OBu}\right), 96.12$ (dyad, $\mathrm{OC}-\mathrm{CH}=$, dion), 127.83-137.97 ( $\mathrm{C}=\mathrm{C}, \mathrm{C}_{6} \mathrm{H}_{5}$, dion), 182.28 $(\mathrm{CH}=\mathrm{C}-\mathrm{O}$, dion, enol form), $184.82(\mathrm{C}=\mathrm{O}$, dion). FTIR $\left(\mathrm{cm}^{-1}\right)$ : 3055, 2954, 2926, 2885, 
$2837,1592,1542,1517,1470,1451,1366$, 1313, 1299, 1226, 1071, 1022, 749, 714, 685, 550. Elemental analysis, $\mathrm{C}_{38} \mathrm{H}_{40} \mathrm{O}_{6} \mathrm{Ti}$ (640.59 $\mathrm{g} / \mathrm{mol})$ : Calc. C 71.25, H 6.29\% ; found: C 69.20, H 6.70\%. Mass spectrum: $641.2386 \mathrm{Da}$ for molecular ion $\left[\mathrm{Ti}\left(\mathrm{OBu}^{\mathrm{n}}\right)_{2}(\text { dion })_{2}+\mathrm{H}^{+}\right.$ $\left(=\mathrm{TiC}_{38} \mathrm{H}_{40} \mathrm{O}_{6}+\mathrm{H}^{+}\right)$.

\section{Reaction of titanium(IV) isopropoxide with 1,3-diphenyl-1,3-propanedione in 1:1 mole ratio (3)}

The reaction of 1,3-diphenyl-1,3propanedione $\left(2.0 \times 10^{-3} \mathrm{~mol}, 0.46 \mathrm{~g}\right)$ with titanium iso-propoxide $\left(2.0 \times 10^{-3} \mathrm{~mol}, 0.59 \mathrm{~g}\right)$ in $20 \mathrm{~mL}$ of isopropanol was carried out similarly to the preceding reaction. ${ }^{1} \mathrm{H}-$ $\mathrm{NMR}\left(\mathrm{CDCl}_{3}, \mathrm{ppm}\right): \delta 1.29\left(\mathrm{~d}, \mathrm{~J}=6.12 \mathrm{~Hz}, \mathrm{CH}_{3}\right.$, $\mathrm{OPr}^{\mathrm{i}}$ ), 5.05 (septet, $\mathrm{J}=6.15 \mathrm{~Hz}, \mathrm{OCH}, \mathrm{OPr}^{\mathrm{i}}$ ), $7.02\left(\mathrm{H}, \mathrm{OC}-\mathrm{C} \underline{\mathrm{H}}=\right.$, dion), $7.38\left(\mathrm{~m}, 2 \mathrm{H}, \mathrm{C}_{6} \mathrm{H}_{5}\right.$, dion), $7.46\left(t, 1 \mathrm{H}, \mathrm{J}=6.92 \mathrm{~Hz}, \mathrm{C}_{6} \mathrm{H}_{5}\right.$, dion), $7.60\left(\mathrm{~m}, 3 \mathrm{H}, \mathrm{C}_{6} \mathrm{H}_{5}\right.$, dion), $7.92(\mathrm{~d}, 2 \mathrm{H}, \mathrm{J}=7.5$ $\mathrm{Hz}, \mathrm{C}_{6} \mathrm{H}_{5}$, dion), 8.25 (d, $2 \mathrm{H}, \mathrm{J}=7.0 \mathrm{~Hz}, \mathrm{C}_{6} \mathrm{H}_{5}$, dion). FTIR $\left(\mathrm{cm}^{-1}\right): 3060,2980,2930,2870$, $1592,1548,1520,1465,1360,1330,1120$, $1005,940,860,618,460$. Elemental analysis, $\mathrm{C}_{24} \mathrm{H}_{32} \mathrm{O}_{5} \mathrm{Ti}(448.37 \mathrm{~g} / \mathrm{mol})$ : Calc. C 64.29, H $7.19 \%$; found: C 62.90, H 6.65\%.

\section{Reaction of titanium(IV) isopropoxide with 1,3-diphenyl-1,3-propanedione in 1:2 mole ratio (4) \\ The reaction of 1,3-diphenyl-1,3- propanedione $\left(4.0 \times 10^{-3} \mathrm{~mol}, 1.0 \mathrm{~g}\right)$ with titanium isopropoxide $\left(2.0 \times 10^{-3} \mathrm{~mol}, 0.59 \mathrm{~g}\right)$ in $20 \mathrm{~mL}$ of isopropanol was carried out similarly to the preceding reaction. ${ }^{1} \mathrm{H}-\mathrm{NMR}$ $\left(\mathrm{CDCl}_{3}, \mathrm{ppm}\right): \delta 0.94\left(\mathrm{CH}_{3}, \mathrm{OPr}^{\mathrm{i}}\right), 3.57(\mathrm{CHO}$, $\left.\mathrm{OPr}^{\mathrm{i}}\right), 7.62(\mathrm{OC}-\mathrm{CH}=$, dion), $7.30-7.89(\mathrm{CH}=$, $\mathrm{C}_{6} \mathrm{H}_{5}$, dion). Elemental analysis, $\mathrm{C}_{36} \mathrm{H}_{36} \mathrm{O}_{6} \mathrm{Ti}$ $(612.53 \mathrm{~g} / \mathrm{mol})$ : Calc. C 70.59, H 5.92\% ; found: $\mathrm{C}: 69.08, \mathrm{H}: 6.37 \%$.}

Reaction of zirconium(IV) butoxide with 1,3-diphenyl-1,3-propanedione in 1:1 mole ratio (5)

1,3-diphenyl-1,3-propanedione (2.0 $\quad$ 10 $10^{-3}$ $\mathrm{mol}, 0.46 \mathrm{~g})$ was added to a solution of zirconium(IV) butoxide $\left(2.0 \times 10^{-3} \mathrm{~mol}, 0.96 \mathrm{~g}\right)$ in $20 \mathrm{~mL}$ of $\mathrm{n}$-butanol. The reaction mixture was stirred for three hours at $35^{\circ} \mathrm{C}$ over an oil bath. Then, the solvent was removed by rotary evaporator at $50{ }^{\circ} \mathrm{C}$ under vacuum. ${ }^{1} \mathrm{H}-\mathrm{NMR}$ (DMSO, ppm): $\delta 0.709\left(\mathrm{CH}_{3}, \mathrm{OBu}\right), 1.14$ ( $\left.\mathrm{CH}_{3}-\mathrm{CH}_{2}{ }^{-}, \mathrm{OBu}\right), 1.25\left(\mathrm{C}_{2}-\mathrm{CH}_{2} \mathrm{O}, \mathrm{OBu}\right), 4.1$ $\left(\mathrm{CH}_{2} \mathrm{O}, \mathrm{OBu}\right), 7.3-7.7\left(\mathrm{C}_{6} \mathrm{H}_{5}\right.$, dion) 7.9 (OC$\mathrm{CH}=$, dion). ${ }^{13} \mathrm{C}-\mathrm{NMR}$ (DMSO, ppm): $\delta 13.8$ $\left(\mathrm{CH}_{3}, \mathrm{OBu}\right), 18.6\left(\mathrm{CH}_{3}-\underline{\mathrm{CH}_{2}}, \mathrm{OBu}\right), 34.6\left(\mathrm{CH}_{2}-\right.$ $\left.\mathrm{CH}_{2} \mathrm{O}, \mathrm{OBu}\right), 70.7\left(\mathrm{CH}_{2} \mathrm{O}, \mathrm{OBu}\right), 95.05(\mathrm{CO}-$ $\mathrm{CH}=$, dion $), 127-137\left(\mathrm{C}_{6} \mathrm{H}_{5}\right.$, dion $), 182.9$ $\left(\mathrm{C}_{6} \mathrm{H}_{5}-\mathrm{CO}\right.$, dion). FTIR $\left(\mathrm{cm}^{-1}\right): 3060(\mathrm{CH}=\mathrm{C}$, asym str), $3027(\mathrm{CH}=, \mathrm{Ph}), 2953\left(\mathrm{sp}^{3}-\mathrm{CH}\right.$, asym str), 2868 ( $\mathrm{sp}^{3}-\mathrm{CH}$, asym str), 1594 $(\mathrm{C}=\mathrm{C}, \mathrm{Ph}), 1546(\mathrm{C}=\mathrm{O}$, asym), 1518 ( $\mathrm{C}=\mathrm{C}$,
$\mathrm{Ph}), 1476,1363$ (C-O, sym), 1222, 1071 (CO, C-C), 745, 682, 617, 430 .

Reaction of zirconium(IV) butoxide with 1,3-diphenyl-1,3-propanedione in 1:2 mole ratio (6)

The reaction of 1,3-diphenyl-1,3propanedione $\left(4.0 \times 10^{-3} \mathrm{~mol}, 1.0 \mathrm{~g}\right)$ with zirconium n-butoxide $\left(2.0 \times 10^{-3} \mathrm{~mol}, 0.96 \mathrm{~g}\right)$ in $20 \mathrm{~mL}$ of $\mathrm{n}$-butanol was carried out similarly to the preceding reaction. ${ }^{1} \mathrm{H}-\mathrm{NMR}\left(\mathrm{CDCl}_{3}\right.$, ppm): $\delta 1.0$ (brd, $\mathrm{CH}_{3}, \mathrm{OBu}$ ), 1.46 (sextet, J= $7.55 \mathrm{~Hz}, \mathrm{CH}_{3}-\mathrm{C}_{2}, \mathrm{OBu}$ ), 1.62 (pentet, J=7.87 $\mathrm{Hz}, \mathrm{CH}_{2}-\mathrm{CH}_{2} \mathrm{O}, \mathrm{OBu}$ ), 3.69 (brd, $\mathrm{CH}_{2} \mathrm{O}, \mathrm{OBu}$ ), $7.08\left(2 \mathrm{H}, \mathrm{OC}-\mathrm{CH}=\right.$, dion), 7.37 (brd, $2 \mathrm{H}, \mathrm{C}_{6} \mathrm{H}_{5}$, dion), 7.44 (brd, $6 \mathrm{H}, \mathrm{C}_{6} \mathrm{H}_{5}$, dion), 7.50 (d, $\mathrm{J}=6.8 \mathrm{~Hz}, 4 \mathrm{H}, \mathrm{C}_{6} \mathrm{H}_{5}$, dion), 8.11 (d, $\mathrm{J}=6.3 \mathrm{~Hz}$, $4 \mathrm{H}, \mathrm{C}_{6} \mathrm{H}_{5}$, dion), $8.16\left(\mathrm{~d}, \mathrm{~J}=6.3 \mathrm{~Hz}, 4 \mathrm{H}, \mathrm{C}_{6} \mathrm{H}_{5}\right.$, dion). ${ }^{13} \mathrm{C}-\mathrm{NMR}\left(\mathrm{CDCl}_{3}, \mathrm{ppm}\right): \delta 13.93\left(\mathrm{CH}_{3}\right.$, $\mathrm{OBu}), 19.01\left(\mathrm{CH}_{3}-\underline{C H}_{2}, \mathrm{OBu}\right), 34.93\left(\mathrm{CH}_{2}-\right.$ $\left.\mathrm{CH}_{2} \mathrm{O}, \mathrm{OBu}\right), 77.43\left(\mathrm{CH}_{2} \mathrm{O}, \mathrm{OBu}\right), 95.81$ (OC$\mathrm{CH}=$, dion), 128.04-138.73 ( $\mathrm{C}=\mathrm{C}, \mathrm{C}_{6} \mathrm{H}_{5}$, dion), 182.88 ( $\mathrm{CH}=\mathrm{C}-\mathrm{O}$, dion, enol form), 183.65 (C=O, dion). FTIR ( $\left.\mathrm{cm}^{-1}\right): 3059,2953,2868$, 1593, 1519, 1476, 2365, 1319, 1220, 1068, $1024,944,719,684,617,534,454$. Mass spectrum: $759.135 \mathrm{Da}$ for $\left[\mathrm{Zr}\left(\mathrm{OBu}^{\mathrm{n}}\right)_{2} \text { (dion }\right)_{2}$ $\left.. \mathrm{C}_{4} \mathrm{H}_{9} \mathrm{OH}+\mathrm{H}\right]^{+}, 683.195 \mathrm{Da}$ for molecular ion $\left[\mathrm{Zr}\left(\mathrm{OBu}^{\mathrm{n}}\right)_{2}(\text { dion })_{2}+\mathrm{H}\right]^{+}$.

Reaction of zirconium(IV) propoxide with 1,3-diphenyl-1,3-propanedione in 1:1 mole ratio (7)

The reaction of 1,3-diphenyl-1,3propanedione $\left(2.0 \times 10^{-3} \mathrm{~mol}, 0.46 \mathrm{~g}\right)$ with zirconium n-propoxide $\left(2.0 \times 10^{-3} \mathrm{~mol}, 0.94 \mathrm{~g}\right)$ in $20 \mathrm{~mL}$ of $\mathrm{n}$-propoxide was carried out similarly to the preceding reaction. ${ }^{1} \mathrm{H}$ $\operatorname{NMR}\left(\mathrm{CDCl}_{3}, \mathrm{ppm}\right): \delta 0.80\left(\mathrm{t}, \mathrm{J}=6.69 \mathrm{~Hz}, \mathrm{CH}_{3}\right.$, $\mathrm{OPr}), 1.46$ (m, $\left.\mathrm{CH}_{3}-\mathrm{C}_{2}, \mathrm{OPr}\right), 3.48,3.90$ (brd, $\left.\mathrm{CH}_{2} \mathrm{O}, \mathrm{OPr}\right), 7.13(\mathrm{H}, \mathrm{OC}-\mathrm{CH}=$, dion), $7.28(\mathrm{t}$, $\mathrm{J}=7.53 \mathrm{~Hz}, 3 \mathrm{H}, \mathrm{C}_{6} \mathrm{H}_{5}$, dion), 7.35 (d, J=7.33 $\mathrm{Hz}, 1 \mathrm{H}, \mathrm{C}_{6} \mathrm{H}_{5}$, dion), 7.79 (d, J=7.22 Hz, 2H, $\mathrm{C}_{6} \mathrm{H}_{5}$, dion), 7.88 ( $\mathrm{t}, \mathrm{J}=7.56 \mathrm{~Hz}, 2 \mathrm{H}, \mathrm{C}_{6} \mathrm{H}_{5}$, dion), 7.96 (d, J=7.22 Hz, $2 \mathrm{H}, \mathrm{C}_{6} \mathrm{H}_{5}$, dion).

\section{Reaction of zirconium(IV) propoxide with 1,3-diphenyl-1,3-propanedione in $1: 2$ mole ratio (8)}

The reaction of 1,3-diphenyl-1,3propanedione $\left(4.0 \times 10^{-3} \mathrm{~mol}, 1.0 \mathrm{~g}\right)$ with zirconium n-propoxide $\left(2.0 \times 10^{-3} \mathrm{~mol}, 0.94 \mathrm{~g}\right)$ in $20 \mathrm{~mL}$ of $\mathrm{n}$-propoxide was carried out similarly to the preceding reaction. ${ }^{1} \mathrm{H}$ $\mathrm{NMR}\left(\mathrm{CDCl}_{3}, \mathrm{ppm}\right): \delta 0.94\left(\mathrm{t}, \mathrm{J}=7.46 \mathrm{~Hz}, \mathrm{CH}_{3}\right.$, $\mathrm{OPr}$ ), 1.59 (sextet, $\mathrm{J}=7.18 \mathrm{~Hz}, \mathrm{CH}_{3}-\mathrm{CH}_{2}, \mathrm{OPr}$ ), $3.57,3.60$ (brd, $\left.\mathrm{CH}_{2} \mathrm{O}, \mathrm{OPr}\right), 7.03(2 \mathrm{H}, \mathrm{OC}-$ $\mathrm{CH}=$, dion), 7.33 (brd, $\mathrm{H}, \mathrm{C}_{6} \mathrm{H}_{5}$, dion), 7.38 (brd, 3H, $\mathrm{C}_{6} \mathrm{H}_{5}$, dion), 7.44 (brd, $2 \mathrm{H}, \mathrm{C}_{6} \mathrm{H}_{5}$, dion), 8.06 (brd, $2 \mathrm{H}, \mathrm{C}_{6} \mathrm{H}_{5}$, dion), 8.10 (brd, $2 \mathrm{H}, \mathrm{C}_{6} \mathrm{H}_{5}$, dion). FTIR $\left(\mathrm{cm}^{-1}\right): 2969,2872$, 2319,1738, 1593, 1538, 1518, 1476, 1454, 1376-1300, 1224, 1182, 1145, 1073, 1008, $969,944,785,751,618$. Elemental analysis, 
$\mathrm{C}_{36} \mathrm{H}_{36} \mathrm{O}_{6} \mathrm{Zr}(655.89 \mathrm{~g} / \mathrm{mol}):$ Calc. $\mathrm{H}: 5.53 \%$; found: $\mathrm{H} 5.40 \%$.

\section{Polymerization of $\varepsilon$-caprolactone with} Ti/Zr-dion complexes (9)

$\mathrm{Ti} / \mathrm{Zr}$-dion complexes $(20 \mathrm{mg})$ were mixed with $\varepsilon$-caprolactone $(1.5 \mathrm{~mL})$ in a vial under nitrogen atmosphere. The mixture was stirred without solvent at $80^{\circ} \mathrm{C}$ for different times as indicated in Table $1 .{ }^{1} \mathrm{H}$ NMR $\left(\mathrm{CDCl}_{3}, \mathrm{ppm}\right): \delta$ $4.08\left(t, j=7.0 \mathrm{~Hz},{ }^{e} \mathrm{CH}_{2}-\mathrm{O}\right), 2.30(\mathrm{t}, \mathrm{J}=7.0$ $\left.\mathrm{Hz},{ }^{\mathrm{a}} \mathrm{CH}_{2}-\mathrm{C}=0\right), 1.67\left(\mathrm{~m}, \mathrm{~J}=7.0 \mathrm{~Hz},{ }^{b}, \mathrm{~d} \mathrm{CH}_{2}\right)$, $1.39\left(\mathrm{~m}, \mathrm{~J}=7.0 \mathrm{~Hz},{ }^{9} \mathrm{CH}_{2}\right) .{ }^{13} \mathrm{C} \mathrm{NMR}\left(\mathrm{CDCl}_{3}\right.$, ppm): $\delta 173.80(\mathrm{C}=0), 64.4\left({ }^{e} \mathrm{CH}_{2} \mathrm{O}\right), 34.3$ $\left({ }^{\mathrm{a}} \mathrm{CH}_{2}\right), 28.6\left({ }^{\mathrm{d}} \mathrm{CH}_{2}\right), 25.7\left({ }^{b} \mathrm{CH}_{2}\right), 24.8\left({ }^{9} \mathrm{CH}_{2}\right)$. $\left[\mathrm{O}=\mathrm{C}-{ }^{\mathrm{a}} \mathrm{CH}_{2}{ }^{\mathrm{b}} \mathrm{CH}_{2}{ }^{\mathrm{g}} \mathrm{CH}_{2}{ }^{\mathrm{d}} \mathrm{CH}_{2}{ }^{\mathrm{e}} \mathrm{CH}_{2} \mathrm{O}-\right]$. FTIR $\left(\mathrm{cm}^{-1}\right)$ : $2940\left(\mathrm{CH}_{2}\right.$, asym str $), 2864\left(\mathrm{CH}_{2}\right.$, sym str), $1720(\mathrm{C}=\mathrm{O}), 1470\left(\mathrm{CH}_{2}\right.$, bending $), 1365$
( $\mathrm{CH}_{2}$, bending), 1292 (C-C), 1240 (C-O-C, asym), 1165 (C-O-C, sym), 1046, 961,730.

\section{RESULTS AND DISCUSSION}

Stoichiometric reactions of 1,3-diphenyl-1,3propanedione with zirconium or titanium alkoxides in $1: 1$ or $2: 1$ molar ratio in corresponding alcohols at $35{ }^{\circ} \mathrm{C}$ produced compounds (1-8). The formulation of compounds was based on combinations of ${ }^{1} \mathrm{H}$, ${ }^{13} \mathrm{C}-\mathrm{NMR}$, FTIR, and mass spectroscopies, and elemental analysis. The structure of compounds can be drawn as seen in Scheme 1 for $1: 1$ mole ratio of 1,3-diphenyl-1,3propanedione to $\mathrm{M}(\mathrm{OR})_{4}$ and $2: 1$ mole ratio of 3-diphenyl-1,3-propanedione to $\mathrm{M}(\mathrm{OR})_{4}$, [ $\mathrm{M}$ OR: Ti-OBun $\left.\left.{ }^{n}, \mathrm{Ti}^{\mathrm{O}} \mathrm{OPr}{ }^{\mathrm{i}}, \mathrm{Zr}^{-} \mathrm{OBu}^{\mathrm{n}}, \mathrm{Zr}-\mathrm{OPr}^{\mathrm{n}}\right)\right]$, respectively.<smiles>COc1ccccc1</smiles><smiles>[R][R]1([R])OC(=O)C=C(c2ccccc2)O1</smiles>

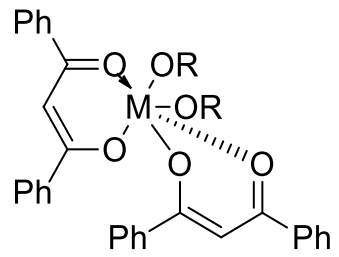

$\mathrm{n}=1, \mathrm{~A}$ $\mathrm{n}=2, \mathrm{~B}$

Scheme 1. Structures of $\left[M(O R)_{3}(\right.$ dion $\left.)\right]$ and $\left[M(O R)_{2}(\text { dion })_{2}\right],\left(M=T i, Z r ; O R=O B u^{n}, \mathrm{OPr}^{n}, \mathrm{OPr}^{\mathrm{i}}\right)$.

High resolution mass spectrometry (ESI-TOFMS) was used to determine the masses of complexes. The samples were measured under positive and negative soft ionization conditions (ES+/ES-). The evaluation of the mass spectra which is based on isotopic patterns clearly showed metal-containing ions.
For example, the mass spectrum of the product resulted from reaction between $1,3-$ diphenyl-1,3-propanedione and $\mathrm{Ti}\left(\mathrm{OBu}^{\mathrm{n}}\right)_{4}$ in $1: 1$ molar ratio gave peaks at 529.184 Da for molecular ion $\left[\mathrm{C}_{27} \mathrm{H}_{38} \mathrm{O}_{5} \mathrm{Ti}+\mathrm{K}\right]^{+}$and at 491.228 Da for $\left[\mathrm{C}_{27} \mathrm{H}_{38} \mathrm{O}_{5} \mathrm{Ti}\right]{ }^{+}$(Figure 1).
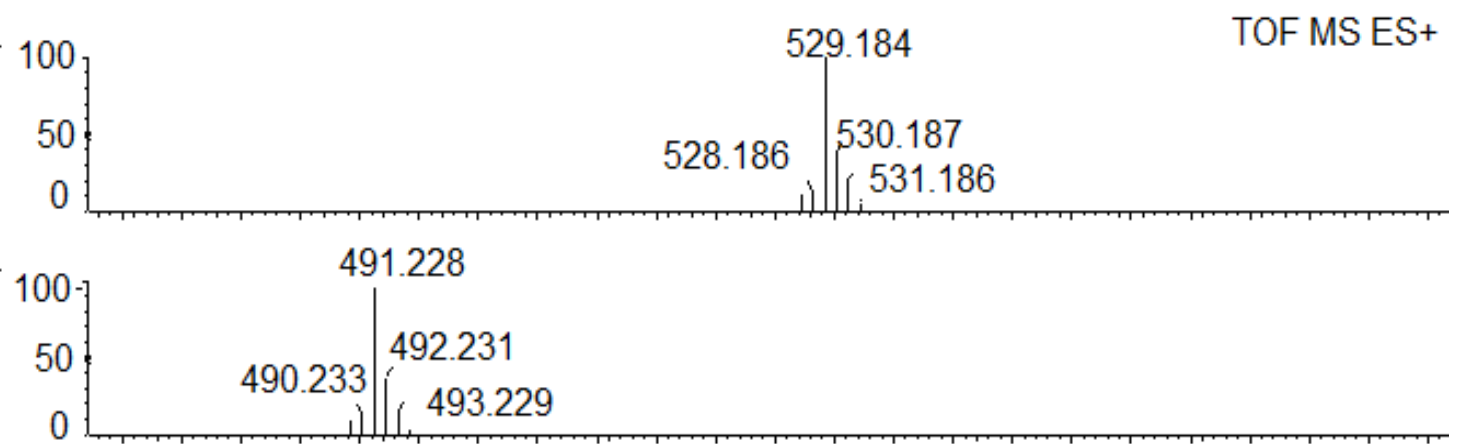

Figure 1. Mass spectrum of $\left[\mathrm{Ti}\left(\mathrm{OBu}^{\mathrm{n}}\right)_{3}\right.$ (dion) $]$ compound. 
The suggested formula of monomeric compound was consistent with elemental analysis and ${ }^{1} \mathrm{H},{ }^{13} \mathrm{C}-\mathrm{NMR}$ and FTIR results. The FTIR spectra of the metal alkoxides $\mathrm{Zr}\left(\mathrm{OBu}^{\mathrm{n}}\right)_{4}, \mathrm{Ti}\left(\mathrm{OBu}^{\mathrm{n}}\right)_{4}$ and others are similar and show no absorption bands in the region of 1500-1800 $\mathrm{cm}^{-1}$. The FTIR spectrum of $\left[\mathrm{Ti}\left(\mathrm{OBu}^{\mathrm{n}}\right)_{3}\right.$ (dion)] shows no free dion groups and but the two stretching vibrations $(C=C$ and $\mathrm{C}=\mathrm{O}$ ) of the enolic form of the $\beta$-diketone at $\sim 1615$ and $1546 \mathrm{~cm}^{-1}$ show that all of dion is bonded to the Ti-butoxide. There was no stretching vibrations of $v(C=O)$ of the keto form of free $\beta$-diketone was at about $1740 \mathrm{~cm}^{-}$ 1 . These results were consistent with literature studies $[5,18] .{ }^{1} \mathrm{H}$ and ${ }^{13} \mathrm{C}$ NMR spectra of compound supported the mass and FTIR spectra. For instance, The ${ }^{1} \mathrm{H}$ NMR spectrum of $\left[\mathrm{Ti}\left(\mathrm{OBu}^{\mathrm{n}}\right)_{3}(\right.$ dion$\left.)\right]$ complex showed the expected peaks and peak multiplicities. For example, ${ }^{1} \mathrm{H} \quad$ NMR spectrum of $\left[\mathrm{Ti}\left(\mathrm{OBu}^{\mathrm{n}}\right)_{3}(\right.$ dion $\left.)\right]$ showed triplets at $0.95 \mathrm{ppm}$ with $\mathrm{J}=7.4 \mathrm{~Hz}$ for $\mathrm{CH}_{3}$ protons, multiplet at $1.54 \mathrm{ppm}$ with $\mathrm{J}=7.4 \mathrm{~Hz}$ for $\mathrm{CH}_{2}$ protons, triplets at $3.73 \mathrm{ppm}$ with $\mathrm{J}=6.4 \mathrm{~Hz}$ for $\mathrm{OCH}_{2}$ protons of butoxide groups cis to dion and triplets at $4.74 \mathrm{ppm}$ with $\mathrm{J}=6.6 \mathrm{~Hz}$ for $\mathrm{OCH}_{2}$ protons of butoxide groups trans to dion in titanium complex (Figure 2). The presence of very small $\mathrm{CH}_{2}$ keto-form protons signal at around $2.35 \mathrm{ppm}$ indicates that dion is predominantly coordinated to the titanium atom in the enolate form. The signal for the $\mathrm{CH}=$ proton of enol-form was at $7.64 \mathrm{ppm}$ in the ${ }^{1} \mathrm{H}$ NMR spectrum. The integration of ${ }^{1} \mathrm{H}$ NMR spectrum indicated that very small amounts of the alkoxide groups underwent hydrolysis and condensation reactions. The deviation less than $2 \%$ in elemental analysis for carbon atoms also supported the presence of small amounts of hydrolysis and condensation reactions.

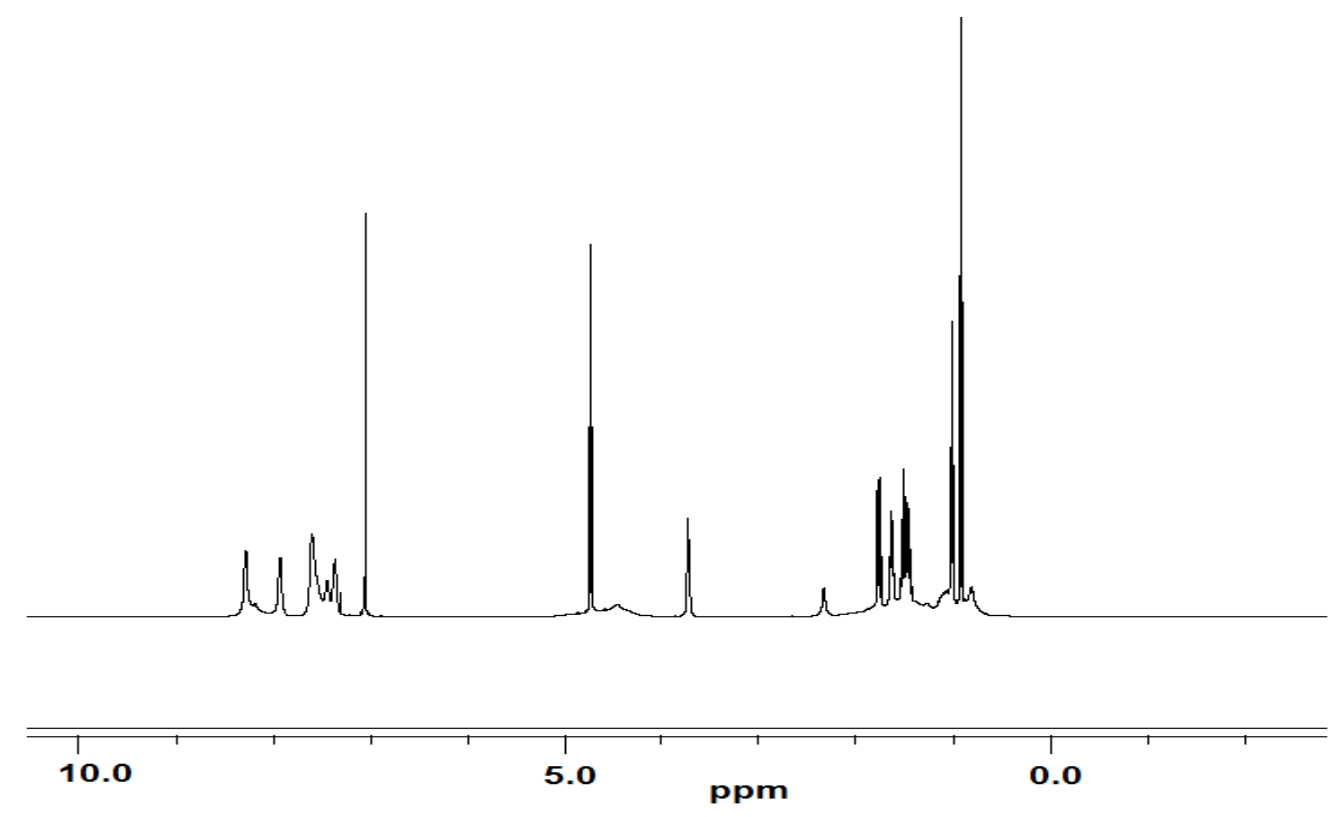

Figure 2. ${ }^{1} \mathrm{HNMR}$ spectrum of $\left[\mathrm{Ti}\left(\mathrm{OBu}^{\mathrm{n}}\right)_{3}\right.$ (dion) $]$.

\begin{abstract}
${ }^{13} \mathrm{C}$ NMR spectrum of $\left[\mathrm{Ti}\left(\mathrm{OBu}^{\mathrm{n}}\right)_{3}\right.$ (dion) $]$ compound (Figure 3 ) gave the expected characteristic peak for enol-form of dion bonded to titanium at $96.13 \mathrm{ppm}$ for $\mathrm{OC}-\underline{\mathrm{C}} \mathrm{H}=$. As seen in the ${ }^{13} \mathrm{C}$ NMR spectrum, there was no peak for carbonyl carbon atom of free ketoform of 1,3-diphenyl-1,3-propanedione at $190 \mathrm{ppm}$ regions. The peaks at 182.28 and $184.82 \mathrm{ppm}$ belongs to $\mathrm{CH}=\mathrm{C}-\mathrm{O}$ (dion, enol form) and 184.82 ( $\mathrm{C}=\mathrm{O}$, dion, enol form), respectively.
\end{abstract}

Reactions 1,3-diphenyl-1,3-propanedione with $\mathrm{M}(\mathrm{OR})_{4}$ in $2: 1$ mole ratio resulted in the formation of $\left[\mathrm{M}(\mathrm{OR})_{2}(\text { dion })_{2}\right]$. All spectroscopic measurements given in the experimental parts support the suggested formulations. The studies of dion/ $\mathrm{Ti}\left(\mathrm{OBu}^{\mathrm{n}}\right)_{4}$ in $2: 1$ mole ratio showed that diones are completely coordinated to titanium atom just in enolate form as drawn in Scheme 1. The mass spectrum of $\left.\left[\mathrm{Ti}\left(\mathrm{OBu}^{\mathrm{n}}\right)_{2} \text { (dion }\right)_{2}\right]$ showed the molecular ion having a mass of 641.2386 $\mathrm{Da}$ (Figure 4). The molecular weight of 641.2386 Da confirmed the suggested formula for the compound prepared from $\mathrm{Ti}\left(\mathrm{OBu}^{\mathrm{n}}\right)_{4}$ and 1,3-diphenyl-1,3-propanedione in 1:2 mole ratio. 


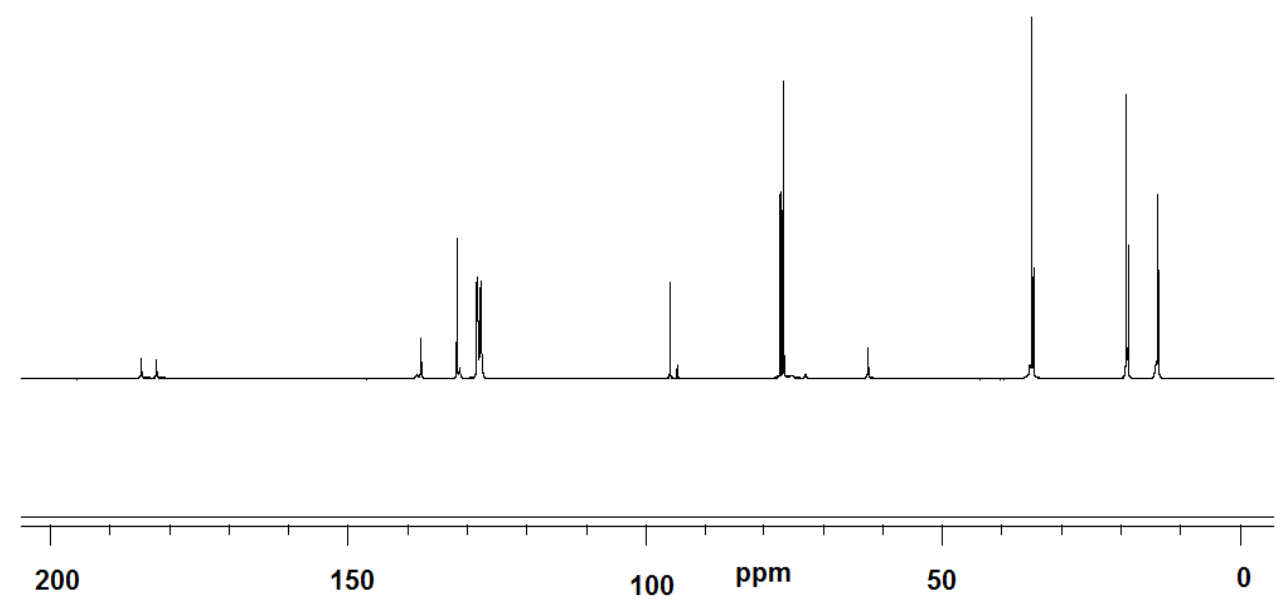

Figure 3. ${ }^{13} \mathrm{C}$ NMR spectrum of $\left[\mathrm{Ti}\left(\mathrm{OBu}^{\mathrm{n}}\right)_{3}(\right.$ dion $\left.)\right]$.

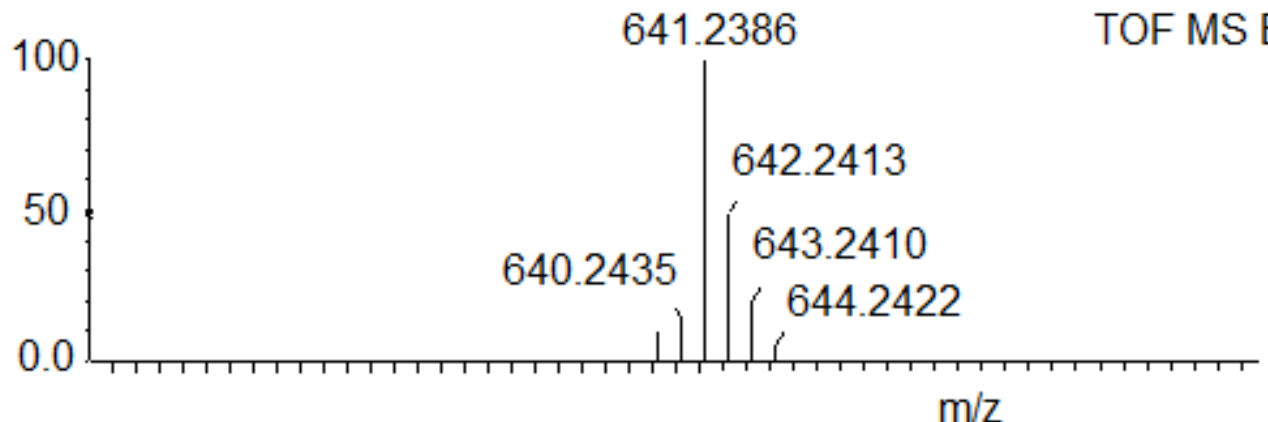

Figure 4. Mass spectrum of $\left[\mathrm{Ti}\left(\mathrm{OBu}^{\mathrm{n}}\right)_{2}(\text { dion })_{2}\right]$.

As in titanium-dion compounds, the reaction between 1,3-diphenyl-1,3-propanedione and $\mathrm{Zr}\left(\mathrm{OBu}^{\mathrm{n}}\right)_{4}$ in $2: 1$ mole ratio resulted in the formation of $\left[\mathrm{Zr}\left(\mathrm{OBu}^{\mathrm{n}}\right)_{2}(\text { dion })_{2}\right]$. The mass spectrum of $\left.\left[\mathrm{Zr}\left(\mathrm{OBu}^{\mathrm{n}}\right)_{2} \text { (dion }\right)_{2}\right]$ showed the molecular ion having a mass of $683.1950 \mathrm{Da}$ for $\left(=\mathrm{ZrC}_{38} \mathrm{H}_{40} \mathrm{O}_{6}+\mathrm{H}^{+}\right) \quad$ (Figure 5). The molecular weight of 683.1950 Da confirmed the suggested formula with the presence of one mole of $n$-butanol.

In contrast to $\beta$-diketone metal alkoxide compounds, the imine, amine, and carboxylate metal alkoxide compounds were resulted in oligomeric structures like tetramer or hexamer structures (19-21). The degree of oligomerization is affected by the acidity or basicity of ligands, stirring times and temperatures of reactions, the freshness of metal alkoxides, solvent types, etc.

The development of "single-site" or "reduced number of active sites" catalysts has been a key goal for producing polymers with controllable molecular weights and low polydispersity index (22). The Ti/Zr-dion complexes were very effective in the polymerization reactions of $\varepsilon$-caprolactone when they were used as catalysts (Table 1 ). For example, $\varepsilon$-caprolactone polymers prepared with $\mathrm{Zr}\left(\mathrm{OBu}^{\mathrm{n}}\right)_{2}$ (dion $)_{2}$ by stirring at $80{ }^{\circ} \mathrm{C}$ for 18 hours, the main peak appeared at 21140 Da for weight average molecular weight $(\mathrm{Mw})$ with a conversion of $78 \%$. 


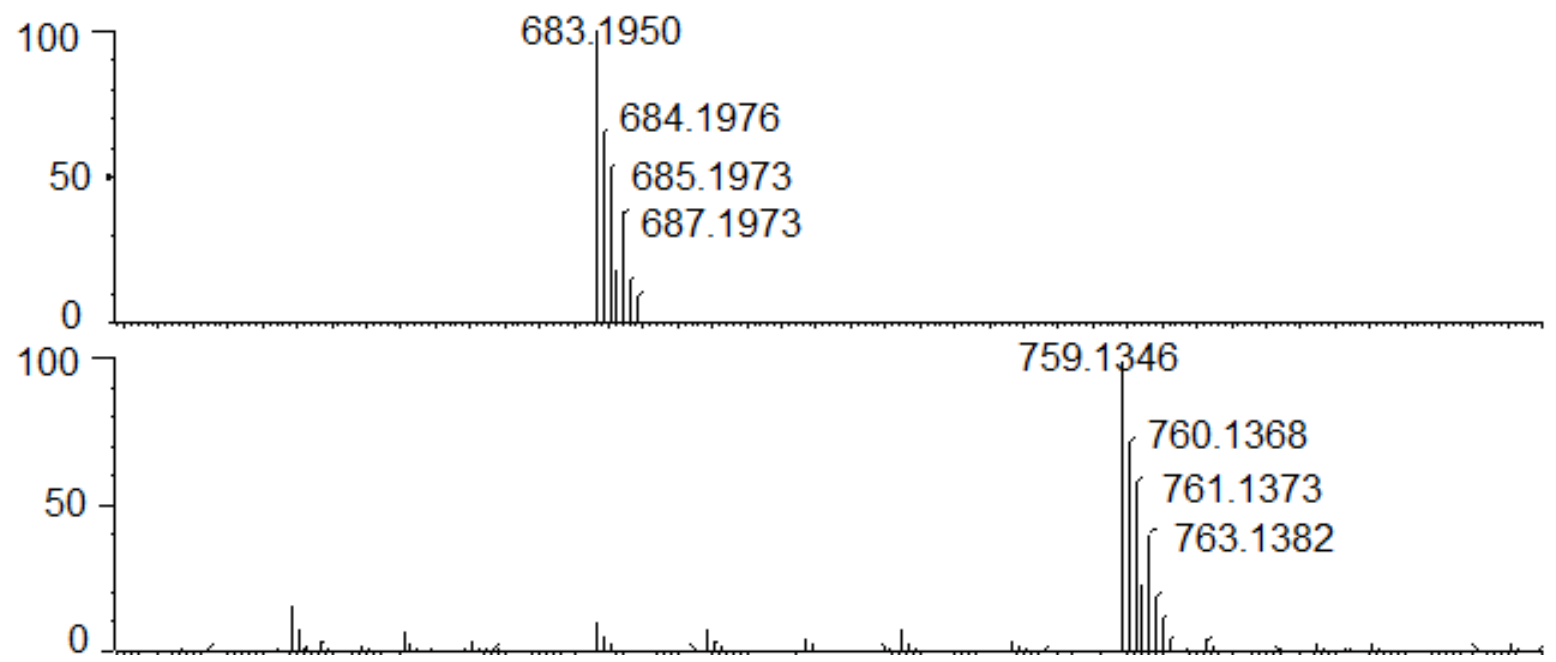

Figure 5. Mass spectrum of $\left[\mathrm{Zr}\left(\mathrm{OBu}^{n}\right)_{2}(\text { dion })_{2}\right] . \mathrm{C}_{4} \mathrm{H}_{9} \mathrm{OH}$.

Metal alkoxide compounds proceed through a coordination-insertion mechanism for the ring opening polymerization (ROP) of $\varepsilon$ caprolactone [23, 24]. In this mechanism (Scheme 2), the Ti/Zr-dion compounds first allow bonding of the $\varepsilon$-caprolactone to the metal center by oxygen atom of the carbonyl group. Then, the nucleophilic alkoxide group attacks the carbon atom of the activated carbonyl group, leading to ester cleavage. Subsequently, $\varepsilon$-caprolactone monomers incorporate to the metal center and insert into the metal-alkoxide bond. Consequently, polycaprolactone with an alkoxide end group is obtained.

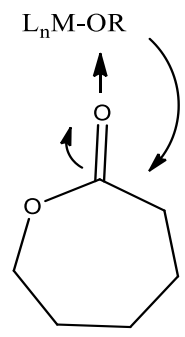

$\mathrm{L}_{\mathrm{n}}=$ Dion

$\mathrm{M}=\mathrm{Ti}, \mathrm{Zr}$

$\mathrm{OR}=\mathrm{OBu}^{\mathrm{n}}, \mathrm{OPr}^{\mathrm{n}}, \mathrm{OPr}^{\mathrm{i}}$

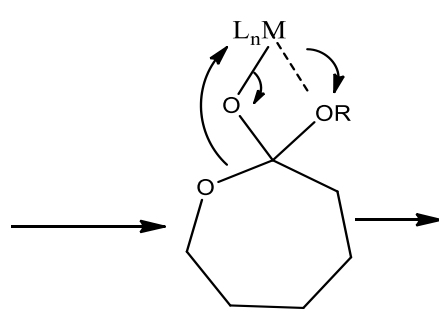<smiles>[Y10]OCCCCCC([R])=O</smiles>

$\mathrm{n}$

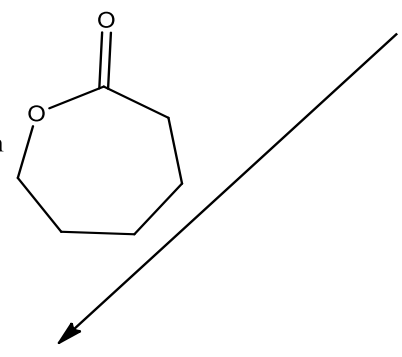<smiles>CC(C)(C)OCCCCCC(=O)C(C)(C)C</smiles>

Scheme 2. Polymerization of $\varepsilon$-caprolactone with $\mathrm{Ti} / \mathrm{Zr}$-dion catalysts.

Each carbon atom of PCL appeared at only one region $173.80(\mathrm{C}=0), 64.4\left({ }^{e} \mathrm{CH}_{2} \mathrm{O}\right), 34.3$ $\left({ }^{\mathrm{a}} \mathrm{CH}_{2}\right), 28.6\left({ }^{\mathrm{d}} \mathrm{CH}_{2}\right), 25.7\left({ }^{\mathrm{b}} \mathrm{CH}_{2}\right), 24.8\left({ }^{\mathrm{g}} \mathrm{CH}_{2}\right)$ ppm in ${ }^{13} \mathrm{C}$-NMR spectrum. These data are the evidence of regular polymerization of $\varepsilon-C L$ and are consistent with the literature data (25).
The $M w, M n$, and PDI values for PCL prepared with metal(dion)alkoxide catalysts at $80^{\circ} \mathrm{C}$ are summarized in Table 1. 
Table 1. Data for PCL obtained from GPC measurements.

\begin{tabular}{|c|c|c|c|c|c|}
\hline Catalysts & Time (h) & $M_{w}(D a)$ & $M_{n}(D a)$ & $\operatorname{PDI}\left(M_{w} / M_{n}\right)$ & Conversion ( $\%)$ \\
\hline $\mathrm{Ti}\left(\mathrm{OBu}^{\mathrm{n}}\right)_{3}($ dion $)$ & 12 & 10640 & 9410 & 1.14 & 54 \\
\hline $\mathrm{Ti}\left(\mathrm{OBu}^{\mathrm{n}}\right)_{3}($ dion $)$ & 24 & 12770 & 11000 & 1.16 & 92 \\
\hline $\mathrm{Ti}\left(\mathrm{OBu}^{\mathrm{n}}\right)_{2}(\text { dion })_{2}$ & 24 & 6990 & 5880 & 1.19 & 45 \\
\hline $\mathrm{Ti}\left(\mathrm{OBu}^{\mathrm{n}}\right)_{2}(\text { dion })_{2}$ & 36 & 8990 & 7300 & 1.21 & 90 \\
\hline $\mathrm{Ti}\left(\mathrm{OPr}^{\mathrm{i}}\right)_{3}$ (dion) & 24 & 13720 & 11780 & 1.16 & 60 \\
\hline $\mathrm{Ti}\left(\mathrm{OPr}^{\mathrm{i}}\right)_{3}$ (dion) & 36 & 15900 & 13475 & 1.18 & 92 \\
\hline $\mathrm{Ti}\left(\mathrm{OPr}^{\mathrm{i}}\right)_{2}$ (dion $)_{2}$ & 36 & 20260 & 16010 & 1.26 & 59 \\
\hline $\mathrm{Zr}\left(\mathrm{OBu}^{\mathrm{n}}\right)_{3}($ dion $)$ & 4.0 & 30820 & 25710 & 1.20 & 44 \\
\hline $\mathrm{Zr}\left(\mathrm{OBu}^{\mathrm{n}}\right)_{3}($ dion $)$ & 10 & 34000 & 27420 & 1.24 & 93 \\
\hline $\mathrm{Zr}\left(\mathrm{OBu}^{\mathrm{n}}\right)_{2}(\text { dion })_{2}$ & 18 & 21140 & 13290 & 1.59 & 78 \\
\hline $\mathrm{Zr}\left(\mathrm{OPr}^{\mathrm{n}}\right)_{3}$ (dion) & 2 & 22420 & 17650 & 1.27 & 66 \\
\hline $\mathrm{Zr}\left(\mathrm{OPr}^{\mathrm{n}}\right)_{2}$ (dion $)_{2}$ & 10 & 17360 & 11970 & 1.45 & 60 \\
\hline $\mathrm{Zr}\left(\mathrm{OPr}^{\mathrm{n}}\right)_{2}(\text { dion })_{2}$ & 16 & 19800 & 13380 & 1.48 & 92 \\
\hline
\end{tabular}

The PDI values for PCL produced using $\left[\mathrm{M}(\mathrm{OR})_{3}\right.$ (dion)] catalysts are noticeably smaller than that for $\mathrm{PCL}$ produced using $\left.\left[\mathrm{M}(\mathrm{OR})_{2} \text { (dion) }\right)_{2}\right]$ catalysts. As seen from Table 1 , the polymerization with $\left[\mathrm{M}(\mathrm{OR})_{2}(\text { dion })_{2}\right]$ catalysts exhibited a slower kinetic of reaction and the polymer synthesized lower weight average molecular weight than with $\left[\mathrm{M}(\mathrm{OR})_{3}(\right.$ dion $\left.)\right]$ catalysts.

The GPC curve of polycaprolactone displayed unimodal behavior with narrow distribution index indicating regular polymerization of $\varepsilon$ caprolactone (Figure 6).

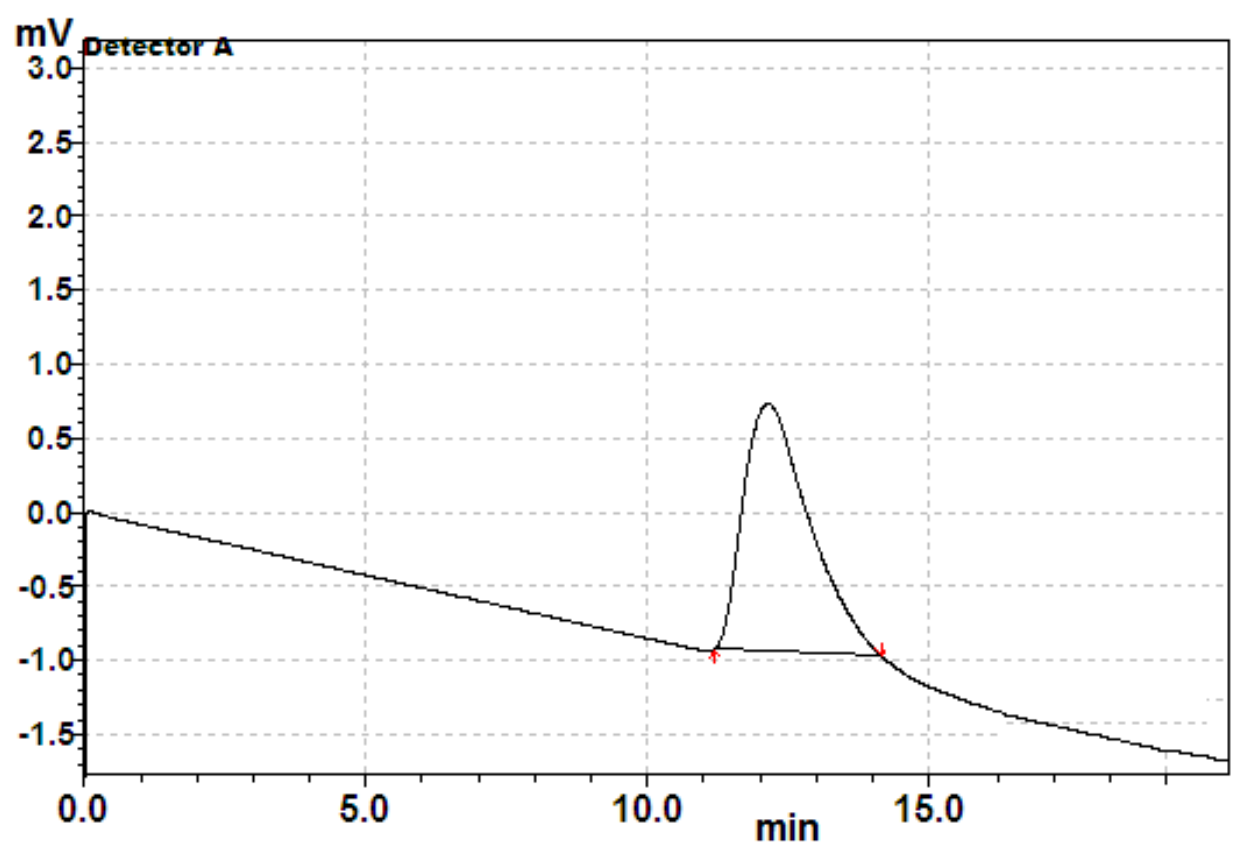

Figure 6. Gel permeation chromatogram of $\mathrm{PCL}$ prepared at $80{ }^{\circ} \mathrm{C}$ with the catalyst $\left[\mathrm{Zr}\left(\mathrm{OPr}^{\mathrm{n}}\right)_{3}\right.$ (dion)].

\section{CONCLUSIONS}

In this study, $\mathrm{Ti} / \mathrm{Zr}$ alkoxide precursors were stabilized by diphenylpropanedione (dion) ligand using sol-gel process. It is interesting to note that the alkoxide groups are significantly more reactive than the $\beta$-diketonate ligands. The $\beta$-diketonate ligands are bidentate ligands and form stronger bonds with the coordinating $\mathrm{Ti} / \mathrm{Zr}$ atom than monodentate (alkoxide) ligands. Therefore, the dion ligands displace the alkoxide groups bonded to $\mathrm{Ti} / \mathrm{Zr}$ atoms. The synthesized $\mathrm{Ti} / \mathrm{Zr}$-dion compounds were characterized by elemental analysis and spectroscopic techniques such as ${ }^{1} \mathrm{H}-,{ }^{13} \mathrm{C}-$ NMR, high resolution mass (HRMS), FTIR. These complexes were used as catalysts on the ring opening polymerization of $\varepsilon$ caprolactone. These results demonstrated that an alkoxide substituent on the 
diphenylpropanedione-Ti/Zr compounds acted as the initiator on $\varepsilon$-caprolactone under solvent-free conditions. As expected, the changes in the number of alkoxide groups bonded to $\mathrm{Ti} / \mathrm{Zr}$ atoms have a dramatic influence not only on the activity of the catalyst, but also on the degree of the polydispersity index and molecular weights of polymers. The aim of this work was to make a contribution to the research for catalyst systems on ROP of E-caprolactone.

\section{ACKNOWLEDGMENTS}

This study has been supported by the Kocaeli University, (project No: 2017/107).

\section{REFERENCES}

1. Mehrotra RC, Bohra R, Gaur DP, Metal $\beta$ Diketonates and Allied Derivatives, Academic Press, London (1978).

2. Fay RC, Lindmark AF. Nuclear magnetic resonance studies of inversion and diketonate R-group exchange in dialkoxybis (. beta.-diketonato) titanium (IV) complexes. Evidence for a twist mechanism. Journal of the American Chemical Society. 1983; 105(8): 2118-2127.

3. Schubert U, Huesing $N$, Lorenz A. Hybrid inorganic-organic materials by sol-gel processing of organofunctional metal alkoxides. Chemistry of materials. 1995; 7(11): 2010-2027.

4. Fleeting KA, O'Brien $P$, Otway DJ, White AJ, Williams DJ, Jones AC. Studies on Mixed $\beta$-Diketonate/Isopropoxide Compounds of Zirconium and Hafnium, the X-ray SingleCrystal Structures of $\left.\left[\mathrm{M}_{2}\left(\mathrm{OPr}^{\mathrm{i}}\right)_{6} \text { (tmhd }\right)_{2}\right](\mathrm{M}=$ $\mathrm{Zr}, \mathrm{Hf})$ : Some Chemistry Important in the MOCVD of Oxides. Inorganic Chemistry. 1999; 38(7): 1432-1437.

5. Hoebbel D, Reinert T, Schmidt H, Arpac E. On the hydrolytic stability of organic Ligands in $\mathrm{Al}-$, Ti-and $\mathrm{Zr}$-alkoxide complexes. Journal of sol-gel science and technology. 1997;10 (2): 115-126.

6. Maurer C, Pittenauer E, Du VA, Allmaier G, Schubert $U$. Cyclic bis ( $\beta$-diketonate)-and bis ( $\beta$-ketoesterate)-bridged titanium and zirconium alkoxide derivatives. Dalton Transactions. 2012; 41(8): 2346-2353.

7. Kurajica S, Skoric I, Mandic V. Ethyl acetoacetate ligand distribution in the course of titanium n-butoxide chelation. Materials Chemistry and Physics. 2014: 147(3): 10581067.
8. Errington RJ, Ridland J, Clegg W, Coxall RA, Sherwood JM. $\beta$-Diketonate derivatives of titanium alkoxides: $X$-ray crystal structures and solution dynamics of the binuclear complexes $\left[\left\{\mathrm{Ti}(\mathrm{OR})_{3}(\mathrm{dik})\right\}_{2}\right]$. Polyhedron. $1998 ; 17(5)$ : 659-674.

9. Kickelbick G, Schubert U. An unusual ring structure of an oligomeric oxotitanium alkoxide carboxylate. European journal of inorganic chemistry. 1998; 1998(2): 159161.

10. Schubert U. Organically modified transition metal alkoxides: Chemical problems and structural issues on the way to materials syntheses. Accounts of chemical research. $2007 ;$ 40(9): 730-737.

11. Yalcin G, Yildiz U, Kayan A. Preparation of $\mathrm{Al}, \mathrm{Ti}, \mathrm{Zr}$-perfluoroheptanoate compounds and their use in ring opening polymerization. Applied Catalysis A: General. 2012; 423: 205-210.

12. Mert, O., Kayan, A. Synthesis of silyliminophenolate zirconium compounds and their catalytic activity over lactide/epoxide. Applied Catalysis A: General. 2013; 464, 322-331.

13. Umare PS, Tembe GL, Rao KV, Satpathy US, Trivedi B. Catalytic ring-opening polymerization of L-lactide by titanium biphenoxy-alkoxide initiators. Journal of Molecular Catalysis. 2007; 268(1-2): 235243.

14. Saridis E, Maroulas SD, Pitsikalis M. Ringopening polymerization of $L$ - lactide using half - titanocene complexes of the $\mathrm{ATiCl}_{2} \mathrm{Nu}$ type: Synthesis, characterization, and thermal properties. Journal of Polymer Science Part A: Polymer Chemistry. 2013; 51(5): 1162-1174.

15. He JX, Duan YL, Kou X, Zhang YZ, Wang $W$, Yang $Y$, Huang $Y$. Dinuclear group 4 alkoxides: Excellent initiators for ringopening polymerization of cyclic esters. Inorganic Chemistry Communications. 2015; 61: 144-148.

16. D'Auria I, Lamberti M, Mazzeo M, Milione S, Roviello G, Pellecchia C. Coordination chemistry and reactivity of zinc complexes supported by a phosphido pincer ligand. Chemistry-A European Journal. 2012; 18(8), 2349-2360.

17. Chisholm. MH, Gallucci JC, Zhen $\mathrm{H}$, Huffman JC. Three-coordinate zinc amide and phenoxide complexes supported by a bulky 
Schiff base ligand. Inorganic chemistry. 2001; 40(19): 5051-5054.

18. Hubert-Pfalzgraf, LG, Cauro-Gamet L, Brethon A, Daniele S, Richard P. (2007). Lanthanide molecular oxohydroxides: Synthesis and characterisation of $\left[\mathrm{Y}_{4}\left(\mu_{4}-\right.\right.$ O) $\left.(\mu-\mathrm{OEt})_{2}\left(\mu, \eta^{2}-\mathrm{AAA}\right)_{2}\left(\eta^{2}-\mathrm{AAA}\right)_{3}\right]_{2}\left(\mu_{3}-\mathrm{OH}\right)_{4}$ $\left(\mu_{3}-\mathrm{OEt}\right)_{2}(\mathrm{HAAA}=$ allylacetatoacetate $)$. Inorganic Chemistry Communications, 2007;10(2): 143-147.

19. Kayan A. Preparation and characterization of TAMP/TIMP-Ti and $\mathrm{Zr}$ compounds and their catalytic activity over propylene oxide and $\varepsilon$ caprolactone. Journal of the Turkish Chemical Society, Section A: Chemistry. 2017; 4(1): 59-80.

20. Schubert U. Silica-based and transition metal-based inorganic-organic hybrid materials-A comparison. Journal of sol-gel science and technology, 2003; 26(1-3): 4755.

21. Faustini M, Nicole L, Ruiz-Hitzky E, Sanchez C. History of Organic-Inorganic Hybrid Materials: Prehistory, Art, Science, and Advanced Applications. Advanced Functional Materials. 2018.

22. Chisholm MH. Trispyrazolylborate ligands as ancillary ligands in the development of single-site metal alkoxide catalysts for ringopening polymerization of cyclic esters. Inorganica Chimica Acta. 2009; 362(12): 4284-4290.

23. Mert O, Kayan A. Synthesis and characterization of substituted salicylate zirconium compounds and their catalytic activity over $\varepsilon$-caprolactone. Journal of Inclusion Phenomena and Macrocyclic Chemistry. 2014; 80(3-4): 409-416.

24. Chmura AJ, Davidson MG, Jones MD, Lunn MD, Mahon MF. Group 4 complexes of amine bis (phenolate) $s$ and their application for the ring opening polymerisation of cyclic esters. Dalton Transactions. 2006; (7): 887889.

25. Yildiz BC, Kayan A. Preparation of singlesite tin (IV) compounds and their use in the polymerization of $\varepsilon$-caprolactone. Designed Monomers and Polymers. 2017; 20(1): 8996. 